\title{
DISRUPTION VERSUS TIEBOUT IMPROVEMENT: THE COSTS AND BENEFITS OF SWITCHING SCHOOLS
}

\author{
Eric A. Hanushek \\ John F. Kain \\ Steven G. Rivkin \\ Working Paper 8479 \\ http://www.nber.org/papers/w8479
NATIONAL BUREAU OF ECONOMIC RESEARCH
1050 Massachusetts Avenue
Cambridge, MA 02138
September 2001

The views expressed herein are those of the authors and not necessarily those of the National Bureau of Economic Research.

(C) 2001 by Eric A. Hanushek, John F. Kain and Steven G. Rivkin. All rights reserved. Short sections of text, not to exceed two paragraphs, may be quoted without explicit permission provided that full credit, including (C notice, is given to the source. 
Disruption versus Tiebout Improvement:

The Costs and Benefits of Switching Schools

Eric A. Hanushek, John F. Kain and Steven G. Rivkin

NBER Working Paper No. 8479

September 2001

JEL No. I2, H4

\begin{abstract}
$\underline{\text { ABSTRACT }}$
Most students change schools at some point in their academic careers, but some change very frequently and some schools experience a great deal of turnover. Many researchers, teachers, and administrators argue that mobility harms students, particularly disadvantaged students in high turnover, inner city schools. On the other hand, economists emphasize the importance of Tiebout type moves to procure better school quality. Empirical research on mobility has yielded inconclusive results, no doubt in part because of small sample sizes and the difficulty of separating mobility effects from other confounding factors. This paper develops a general theoretical model that identifies school quality changes resulting from moving. The empirical analysis, which exploits the rich longitudinal data of the UTD Texas Schools Project, disentangles the disruption effects associated with moves from changes in school quality. The results suggest that there is a small average increase in school quality for district switchers, while there is no evidence that those switching schools within districts obtain higher school quality on average. Perhaps most important for policy, the results also show a significant externality from moves: students in schools with high turnover suffer a disadvantage, and the cost is largest for lower income and minority students who typically attend much higher turnover schools.
\end{abstract}

Eric A. Hanushek Hoover Institution Stanford University Stanford, CA 94305-6010 and NBER hanushek@hoover.stanford.edu
John F. Kain

Green Center for the Study

of Science and Society

University of Texas at Dallas

P.O. Box 830688

Richardson, TX 75083-0688
Steven G. Rivkin

Department of Economics

Amherst College

Amherst, MA 01002 


\title{
Disruption versus Tiebout Improvement: The Costs and Benefits of Switching Schools
}

\author{
by Eric A. Hanushek, John F. Kain, and Steven G. Rivkin*
}

Switching schools is a common occurrence for children in the United States. In Texas public schools, for example, almost 50 percent of children switch schools at least once between grades four and seven even excluding changes due to the transition from elementary to middle school. Common perceptions of the implications of school moves, however, differ dramatically by the underlying perspective. Moves dictated by divorce, job loss, or similar events would be expected to disrupt academic progress, while "Tiebout" mobility, with parents changing districts in pursuit of higher quality schools or better matches for their children, would generally be thought of as achievement-enhancing. Frequent school changers, such as children of migrant workers and those who live in economically disadvantaged families, evoke particular concern. The combination of school instability with the pressures of economic disadvantage and limited community roots might be expected to diminish seriously prospects for academic success.

Prior evidence suggests that mobility is on average harmful to students, although the evidence is mixed. In many studies the relationship is not statistically significant, and some papers report a positive relationship between achievement and mobility (see Alexander, Entwisle and Dauber 1996). Kerbow (1996) finds that most students recover fully two years following a move but that frequent movers lose ground relative to other students. Yet interpretation of these results is complicated by the fact that movers and non-movers appear to differ along a number of dimensions related to school performance. Movers, particularly those who move multiple times, tend to have lower family income, to be Black or Hispanic,

* Stanford University, National Bureau of Economic Research, and University of Texas at Dallas; University of Texas at Dallas; and Amherst College and University of Texas at Dallas, respectively. An earlier version of this paper was presented at the annual meeting of the Society of Labor Economists, May 1999. We benefited from helpful comments by Derek Neal, David Neumark, and seminar participants at the Institute for Research on Poverty meetings, the Public Policy Institute of California, the SOLE meetings, and the NBER summer meetings. The analysis in this paper has been supported by grants from the Smith Richardson Foundation, the William H. Donner Foundation, the Packard Humanities Institute, and the Mellon Foundation. 
and to have lower initial achievement. Thus several recent studies unsurprisingly show that controls for family background and pre-move achievement levels reduce the magnitude and statistical significance of moving effects, often to the point that hypotheses of no mobility effects cannot be rejected. ${ }^{1}$

There is even less evidence on the change in school quality following a move despite the emphasis on school quality differences in many theoretical models of neighborhood and school choice (e.g., Fernandez and Rogerson 1997; Epple and Romano 1998; Nechyba 2000). One problem is the difficulty of disentangling the effects of switching schools per se from concurrent changes in school quality. Kain and O’Brien (1999) suggest that moves that ultimately benefit students might appear costly if achievement is measured only in the year following the move. A recent study by Cullen, Jacobs and Levitt (2000) examines the change in school quality for students who choose to take advantage of open enrollment and opt out of their neighborhood school in Chicago. Except for students attending a trade school, the there is little or no evidence that students systematically procure better school quality by choosing to travel to a non-neighborhood school.

Finally, a less discussed aspect of mobility is its effect on other students. Large student turnover can disrupt orderly teaching and curriculum development, implying potentially serious externalities from mobility. Because movers are more likely to attend schools with higher turnover, it is important to separate the direct effects of moving from the effects of high turnover in the school.

This paper investigates the heterogeneous effects of different kinds of moves on students and their schoolmates using longitudinal information on students found in the extraordinarily rich data set constructed under the UTD Texas Schools Project. The large number of movers in this data set, which follows several entire cohorts of Texas elementary school students for a number of grades, permits detailed investigation of different types of moves and their implications for specific demographic groups.

\footnotetext{
${ }^{1}$ Alexander, Entwisle and Dauber (1996) and Ingersoll, Scamman and Eckerling (1989) both find that controls for family socio-economic status diminish estimated moving effects, and Alexander et al. find that control for initial academic achievement generally produces estimated moving effects that are not significantly different from zero. Kain and O’Brien (1998), however, find significant negative impacts of all kinds of mobility, even after conditioning on initial achievement.
} 
Most importantly, mobility effects are identified by comparisons of academic performance before and after a move for the same student, a superior approach to relying just on comparisons between movers and non-movers.

The analysis permits an investigation of several facets of student mobility that have entered into past research and policy discussions. The effects of moves that take place at various times during the year are considered, as are the consequences of moving multiple times during a single year. Movers who switch school districts are compared with those who remain in the same district with particular attention given to differences by race, ethnicity, and income because of the heterogeneity in mobility propensity, family circumstances and school quality.

The empirical model highlights the inherent difficulty in identifying pure school quality effects as distinct from correlated changes in family circumstances or from normal disruptions following a transfer to a new school. The estimation of school quality relies on long run effects on achievement gains that minimize contamination by short run costs. By comparing different types of moves, it is then possible to distinguish students who tend to be hurt from those who tend to be helped.

The results suggest that on average there is a small but consistent increase in academic achievement for district switchers, because they are able to procure improved school quality. In contrast, those switching schools within district and especially those moving more than once in a school year appear to suffer short run losses and obtain no significant improvements in school quality. Perhaps most important for policy, the results also show that students in schools with high turnover suffer a disadvantage, and the cost is largest for lower income students who typically attend much higher turnover schools. 


\section{A National Portrait of Student Mobility ${ }^{2}$}

While the large amount of residential mobility in the U.S. has been recognized, its translation into school movements is less well understood. To provide an overview of student mobility, we begin with a national picture of mobility for children age 9-14, the relevant age group for our subsequent analysis. This picture, derived from the NLSY79 database, describes residential moves over the two year period of 1994-96. Though children may change residences without changing schools, particularly if they remain in the same district, these figures provide a broad sense of the magnitude of mobility for elementary school age children.

Table 1 shows that 45 percent of young students will undergo a residential move during this two year period. Of the movers, 70 percent will remain in the same school district, but 30 percent will find a different district. ${ }^{3}$ Most of the time, the new district will be within the same metropolitan area, although 17 percent originally reside outside of a Metropolitan Statistical Area (MSA) and 10 percent of the movers originating in MSAs will go to a new MSA (not shown). The mobility rates of disadvantaged students (family income $<175$ percent of the poverty level in 1996) are nine percentage points higher than advantaged students during this period. ${ }^{4}$

Movers also tend to experience a variety of other changes concurrent with their moves. As shown in Table 2, changes in family status - divorce or marriage - are more frequent for movers than nonmovers, particularly for disadvantaged students. ${ }^{5}$ Employment changes for mothers also frequently accompany moves, although the rate of employment change is not much different for movers than for

\footnotetext{
${ }^{2}$ We are indebted to Pat Reagan and Qing Liu for constructing the necessary data set and for producing the tabulations from the NLYS that we report in this section.

${ }^{3}$ These data do not provide information on whether school changes accompany within district moves. The subsequent data for Texas track students across individual schools including within district moves.

${ }^{4}$ The Current Population Survey generally finds lower rates of moving in each category, although there are similar overall patterns for within and across metropolitan areas. Interestingly, its detailed consideration of moving causes does not attempt to investigate whether moving behavior is related to public services or schools; see Schacter (2001a, 2001b). For within county movers, 26 percent move for family-related reasons, 6 percent for work-related reasons, and 65 percent for housing-related reasons. The largest categories in housing-related are wanting a new or better house and wanting to own a house followed by other which might include public goods and services.

${ }^{5}$ Divorce and job loss lead to increased poverty rates, implying that some of the differences by poverty status at the end of the period reflect the impact of these factors. 
nonmovers. ${ }^{6}$ On the other hand, employment changes of fathers (actually spouses of mothers) are much more likely for movers than non-movers, especially for disadvantaged families.

The higher incidence of changes in family structure and employment for movers demonstrates the fact that mobility is not a random event. Without detailed information on family decision-making, it is difficult to know whether a desire to move precipitates a job switch or visa versa or whether a change in family structure leads to relocation of the family. This complicates a study of school mobility, because it is difficult to disentangle the effects of the move per se on a child's academic performance from the effects of the events surrounding the move. On average Table 2 suggests that events associated with moves have a negative impact due to the fairly high incidence of divorce, though the degree of disruption likely varies a great deal from family to family and many movers, such as those who procure much better employment, experience positive changes in family life.

\section{An Empirical Model of Mobility Effects}

The differences in mobility rates by race and income in combination with the high incidence of divorce and job change associated with moves introduce serious complications into the analysis of mobility effects on achievement. Recent work has given more attention to potential differences between movers and non-movers (see Alexander et al.1996), but the potential for unobserved factors to contaminate estimates of mobility effects is quite real even in studies that control for observable differences between movers and nonmovers. In this section we describe a theoretical framework that attempts to disentangle the various aspects of mobility and generates an empirical model that can distinguish changes in school quality from other consequences of mobility.

\footnotetext{
${ }^{6}$ The one exception is a noticeably lower rate of employment change for spouses of disadvantaged mothers in the nonmover category. 


\section{Theoretical Framework}

We begin with a general model of the educational process that highlights important ways through which mobility may affect achievement. Much of the past work on mobility has been correctly criticized for looking just at simple relationships between moving and current achievement, but even the inclusion of a variety of contemporaneous measures of family and school characteristics does not permit identification of the effects of moving. Because achievement depends upon the entire past history of family, community and school inputs including mobility, the data requirements to model the entire achievement process are generally prohibitive. Our development here considers how longitudinal data on achievement and mobility can be used to identify parameters of interest.

Consider a value-added model of achievement growth in which annual learning $(\Delta \mathrm{A})$ for student $\mathrm{i}$ in school $\mathrm{s}$ in year $\mathrm{t}$ is a function of individual, family and school factors. We concentrate on annual gains in achievement not only to relate the timing and pattern of moves directly to school outcomes but also to deal with the other well known estimation problems that arise in estimating achievement models. ${ }^{7}$ To emphasize how school mobility enters, we write this to highlight the distinction between fixed factors and time varying factors such as:
Eq. 1

$$
\begin{aligned}
\Delta A_{i s t} & =A_{i s t}-A_{i, s-1, t-1} \\
& =S Q_{i s t}+\gamma_{i}+\delta_{i t}+\varepsilon_{i s t}
\end{aligned}
$$

\footnotetext{
${ }^{7}$ Since the level of achievement at any point will be related to cumulative family and school inputs to the time, value-added models can circumvent problems of omitted or mismeasured past inputs. Some value added models put lagged test score on the right hand side, which allows its coefficient to differ from one. However, the inclusion of an endogenous variable on the right hand side that is a noisy measure of achievement introduces a number of statistical problems. In any event, preliminary work showed that coefficients on variables of interest were not sensitive to the form of the value added model. See Rivkin, Hanushek, and Kain (2001) for the development of a comprehensive model of education production. 
where SQ indicates school quality, $\gamma$ captures all fixed family and individual influences on achievement, and $\delta$ captures influences that vary over time. From this, school quality determines the expected growth in learning net of individual and family factors.

A key element of our analysis centers on school quality and its relationship to moving. School quality (SQ) can be thought of as being composed of a common component across all students in the school $(\omega)$ and a component that varies within schools $(\theta)$ and is a function of individual student mobility status $\left(\mathrm{m}_{\mathrm{it}}\right)$ :

Eq. $2 S Q_{i s t}=\omega\left(\widetilde{\omega}_{s}, \bar{m}_{s t}\right)+\theta\left(\bar{m}_{s t}, m_{i s t}\right)$

While there is considerable heterogeneity in education quality within schools (Rivkin, Hanushek, and Kain 2001), we think of the common component $(\omega)$ as capturing the overall school quality differences that will enter into any school choice/moving decisions of families. The key elements of $\omega$, which we refer to as "effective school quality," are a fixed overall quality $(\widetilde{\omega})$ and the level of mobility in the school $(\bar{m}) .{ }^{8}$ The fixed component incorporates the quality of the staff, the available resources, peers, and the curriculum, while the separate mobility component highlights the possibility that aggregate mobility rates affect the quality of education for all students. More student turnover may harm the overall instructional program as increased time is spent bringing all students to the same point in the curriculum, developing normal procedures, integrating parents into the school programs, and so forth.

Equation 2 also makes explicit the fact that school quality for new entrants may differ from school quality for incumbent students, as denoted by $\theta$ which is a function of both individual and

\footnotetext{
${ }^{8}$ Our previous analyses of within school heterogeneity in teacher quality (Rivkin, Hanushek, and Kain 2001) is entirely consistent with this description of school quality where the fixed quality component $(\widetilde{\omega})$ is the stable fixed component incorporating average teacher quality, resources, curriculum, and the like and individual classrooms deviate around this according to teacher quality. 
aggregate mobility. Schools may assign new entrants to worse (better) teachers $\left(\theta_{\text {ist }}\right)$, and schools likely vary in the time it takes for new entrants to assimilate academically (possibly a function of the aggregate entry rate, $\left.\bar{m}_{s t}\right)$.

Importantly, mobility also affects achievement independent of school quality. Students must establish themselves in a new community, make new friends, and learn new "operating procedures" at school. This has the character of school-specific human capital that is acquired on the task. In our framework, the time varying individual component $(\delta)$ is in part a function of mobility, but it is not directly related to the level of school quality.

The derivative of equation (1) reveals the net effect on school achievement associated with a move in year $\mathrm{t}$ :

Eq. $3 \frac{\partial(\Delta A)}{\partial m_{i t}}=\underbrace{\frac{\partial \omega}{\partial \widetilde{\omega}} \frac{\partial \widetilde{\omega}}{\partial m_{i t}}+\frac{\partial \omega}{\partial \bar{m}} \frac{\partial \bar{m}}{\partial m_{i t}}}_{\text {pureTiebout }}+\underbrace{\frac{\partial \theta}{\partial \bar{m}} \frac{\partial \bar{m}}{\partial m_{i t}}+\frac{\partial \theta}{\partial m_{i t}}}_{\text {school assimilation }}+\underbrace{\frac{\partial \delta}{\partial m_{i t}}}_{\text {disruption }}$

The first four terms on the right hand side capture the impact of mobility via school quality. The first is the choice of different overall quality that comes with residential location and mobility choices. The second represents the coupled choice of overall school mobility level $(\bar{m})$ that accompanies a move and that works through its affect on effective school quality. The next two terms reflect the ability of the school to assimilate movers. The final term represents the "pure" disruptive effect of mobility on the individual component of learning, part of which is the loss of school specific capital built up prior to the move. The first two terms form the "pure Tiebout" effect, which indicates how a move relates to changes in overall school quality determined by school operations, peers and turnover; the third and fourth terms capture a school's treatment of new students; and the final term reflects disruptive effects on achievement that are independent of the level of school quality.

The signs on the respective derivatives determine the change in learning following a move. As we 
emphasize throughout the paper, students switch schools for a variety of reasons, only some of which are related to school quality. Some will experience a severe disruption; for others it will be minor. Some movers will transfer to better schools, others to worse schools. The sign and magnitude of a mobility coefficient estimated over the entire sample will reflect the relative frequencies of particular changes in school quality, the treatment of new entrants, and the magnitudes of disruptions. Not only do we attempt to separate the average change in school quality from other aspects of moving, but we also divide movers on the basis of move timing, frequency, distance and student demographics, all of which may be related to the change in school quality and degree of disruption.

Prior to discussing the estimation and identification of parameters, one final aspect of mobility is important. The previous descriptions were derived from the perspective of the potential mover. In particular, we have portrayed $\partial \bar{m} / \partial m_{i t}$ as the difference in aggregate mobility rates between the sending and receiving schools. However, the addition of another mover directly increases $\bar{m}_{s t}$, which in turn potentially affects school quality and the assimilation of other movers. This effect, presumably ignored by families in making their mobility decisions, involves a fundamental externality that we explicitly consider in the estimation and evaluation below.

\section{Regression Model}

The task of identifying the pathways through which mobility affects learning is quite difficult, and it is complicated by the fact that moving is not a random event. Rather it involves an active decision process that can be precipitated by a number of factors, some of which may be related to achievement. In the context of equation (1), a change in family circumstances $(\delta)$ may both cause a move and affect achievement directly. Consequently, it is quite easy to confound the mobility effect with that of divorce, job loss, or other factors that precipitate a move.

Our approach takes advantage of the availability of multiple test score observations per student. Consider regression equation (4) in which achievement growth is regressed on an indicator variable 
$\left(m_{i s t}\right)$ for whether the student moved prior to or during year $\mathrm{t}$, an individual fixed effect $\left(\gamma_{i}^{*}\right)$, time varying individual factors $\left(\mathrm{x}_{\mathrm{it}}\right)$, and a random error.

Eq. $4 \Delta A_{i s t}=m_{i s t} \lambda+x_{i t} \beta+\gamma_{i}^{*}+v_{i s t}$

The expectation of the mobility effect in period $t$ is found by taking the expectation of equation 3 across all movers $\left(\lambda=E\left(\partial \Delta A / \partial m_{i t}\right)\right.$. While this formulation is a noticeable improvement over many of the existing estimates of mobility effects, it suffers from two major problems. ${ }^{9}$ First, unless confounding influences that precipitate moves are fully accounted for, the coefficient on $\mathrm{m}_{\mathrm{it}}$ will not provide a consistent estimate of the causal effect of moving on achievement. Second, without information about the separate components of $\lambda$ delineated in equation 3 , both the interpretation and the relevance for policy purposes will be quite limited.

An important objective is the identification of the change in school quality following a move. There is abundant evidence that observable variables such as expenditures, class size, teacher experience and education or even peer group quality capture little of the actual variation in school quality, meaning that we cannot simply add these characteristics to the specification and examine the change in the mobility coefficient to determine the average change in school quality. Moreover, non-movers provide no information on school quality, because the student fixed effect $\left(\gamma_{i}^{*}\right)$ incorporates all of the fixed inputs (including school quality for nonmovers) to achievement growth over the time period analyzed.

By using information on achievement gains for more than two years, however, it is possible to disentangle the change in school quality from the other components of mobility. Equation (5) adds an

\footnotetext{
${ }^{9}$ Two fundamental limitations of existing estimates are apparent from equation 4. First, common estimates typically attempt to use cross-sectional information instead of the achievement growth formulation here. This approach entangles moving effects with current and past influences of family and schools. Second, when value added formulations are employed, the estimation typically relies on explicit measures of family and school circumstances instead of the fixed effect approach here. The validity of such analysis depends crucially on having adequate explicit measures, something that has proved elusive in past work. 
additional mobility term $\left(m_{i s t}^{*}\right)$ equal to one for students who moved to school $\mathrm{s}$ in a previous year and zero otherwise:

Eq. $5 \quad \Delta A_{i s t}=m_{i s t} \lambda+m_{i s t}^{*} \lambda^{*}+x_{i t} \beta+\gamma_{i}^{*}+v_{i s t}$

The estimate of $\lambda^{*}$ reflects the average difference in learning between years following a move and the year prior to the move. ${ }^{10}$ What factors contribute to this difference? In terms of equation (3), we argue that only the two "pure Tiebout" factors associated with differences in school quality systematically determine the size of $\lambda^{*}$. This argument assumes that all assimilation and disruption costs including the acquisition of school specific human capital occur in the first school year (i.e., $E\left[\partial \delta / \partial \mathrm{m}^{*}\right]=0$ ) and that movers are treated as incumbent students after the first year (i.e., $\mathrm{E}\left[\partial \theta / \partial \mathrm{m}^{*}\right]=0$ ). What remains is the persistent difference in school quality. It is natural in this framework to consider $\lambda$ to be the gross temporary effect on the rate of learning and $\lambda *$ to be the steady state change in the rate of learning following a move. By the description of achievement in equation 2, after considering individual and family impacts, the systematic influence on learning comes from school quality.

The identification of the average change in school quality rests on three primary assumptions related to the achievement patterns of nonmove factors:

A1) Students do not on average experience temporary losses in the year prior to the move.

Because school quality is estimated by the rate of growth of achievement after a move compared to that before a move, temporary declines prior to the move, similar to a preprogram dip prior to entering job training, would bias upward the estimated change in school quality. ${ }^{11}$ We can directly investigate the existence of such temporary declines by including dummy variables that identifies changes in achievement growth in the year prior to a move (each for a particular type of move).

\footnotetext{
${ }^{10}$ Note that when $\mathrm{m}^{*}=1, \mathrm{~m}=0$ and visa versa. If the person never moves, both equal zero.

${ }^{11}$ Heckman and Smith (1999) discuss the implications of a preprogram decline for the estimation of job training program effects. 


\section{A2) Absent other factors including a change in school quality, students tend to recover to pre-}

move achievement growth rates in the years subsequent to the disruption period of the move. An

alternative model, albeit one inconsistent with the underlying conceptual model, is that students tend to return to "equilibrium" achievement levels after disruption, i.e., to the achievement that they would have had in the absence of disruption. In this latter case, $\hat{\lambda} *$ would confound the average change in school quality with the recovery from the disruption associated with the move. Two sensitivity tests provide evidence on the alternatives. The first separates $\mathrm{m}^{*}$ into an indicator for one year after a move and an indicator for two years after the move. If students were to recover to the achievement level they would have had in the absence of disruption, average gains in the year following the move should be much larger than those in the second year following the move. On the other hand, recovery in terms of achievement growth would find little or no difference in average gains one and two years after the move. The second test divides movers by origin and destination community types to examine whether those students making what would appear to be school improving moves actually experience a larger average change in school quality. Specifically, we divide district movers into four categories: urban to urban and non-urban to urban (which we expect are less likely to produce average school quality improvements), and urban to non-urban, and non-urban to non-urban (which we expect are more likely to produce school quality improvements). ${ }^{12}$

\section{A3) Extraneous disruptions that accompany a move do not have lingering effects that last more}

than a year. While the student fixed effects capture any changes that persist throughout the period of the sample, changes that accompany the move and persist in the subsequent years could lead to some misestimation of school quality effects. Comparisons of achievement growth one and two years following a move provide information on this, because lingering effects that on average diminish over time would yield an increasing pattern of achievement growth, instead of the constant average pattern implied by school quality effects. This test is not informative for a sample in which the average long term

\footnotetext{
${ }^{12}$ Urban districts are the largest district within the central city of metropolitan areas, while non-urban covers suburban and rural areas outside of these. Note, however, that Texas districts are not coterminous with political jurisdictions, which have sometimes expanded greatly through annexation. 
effect of disruptions is constant over the long run. Not only is this situation highly unlikely, but also the common candidates for such longer lasting disruptions tend to be negative effects such as divorce, implying, if anything, that any estimates of school quality differences derived from $\lambda *$ will be underestimates of the true differences.

Once the estimate of the change in school quality is obtained from $\lambda^{*}$, it can be used to estimate the magnitude of the transitory disruption $\operatorname{cost} \lambda-\lambda *$. However, it is very difficult to separate this difference into the underlying factors described in equation (3). The components involve both adjustments in school and those unrelated to school. Even data on timing of events such as divorce or job loss - which we do not have available - present problems since the events per se might not adequately indicate the time periods of any disruption. Therefore we emphasize the general size of disruption effects rather than the precise magnitudes or the attribution to different causes.

To this point we have focused on the identification of the effects of moving for students who switch schools, but it is also possible to identify the impact of average turnover on learning for movers and nonmovers alike. Specifically, using the entire sample of students, we can estimate the impact of $\bar{m}_{s t}$ on school quality. ${ }^{13}$ Because turnover is undoubtedly correlated with other determinants of school quality, simply including $\bar{m}_{s t}$ into equation (5) as an additional regressor is unlikely to generate a consistent estimate of the externalities. Therefore we employ an alternative approach that also removes school-bygrade fixed effects and thereby identifies the effect of average turnover from within school differences in outcomes for different cohorts in different grades. A natural extension, concentrating on the timing of moves, divides entrants into those who arrive prior to the start of the school year and those who arrive during the year in order to see if midyear arrivals are more disruptive to learning.

One final interpretative issue is important. The preceding development has not been explicit about the underlying causes and motivations for moving. Undoubtedly, individuals differ widely in the

\footnotetext{
${ }^{13}$ As discussed previously, nonmovers contribute nothing to estimation of the fixed school quality term in equation 5 , since this is included in the individual fixed effect, $\gamma_{i}^{*}$. Since $\bar{m}_{s t}$ varies across time and cohorts, however, nonmovers can be used to estimate the effect of student turnover on school quality. 13
} 
decisions to move. For simplicity, assume that there are two types of families: those motivated to move largely because of nonschool factors and those motivated largely by Tiebout school quality concerns. For the former group, such as those moving to accommodate a new job location, the change in school quality may be entirely incidental, and one might not expect to see much relationship between moving and school quality. For the latter, the opposite would hold. For example, it has frequently been asserted that disadvantaged students, particularly those moving within the same school district, are more likely to face disruptive moves. Moves within the same district, even if predicated on observed school quality differences, probably involve more uncertainty about future school quality differences. ${ }^{14}$ It is also asserted that more advantaged students and particularly those changing school districts are more likely to be looking for better school quality. Finally, families changing to an entirely new metropolitan area are more likely to be driven by pure job location decisions and typically will not have access to especially detailed information about schools such as would come from living in a given metropolitan area for a number of years. While the distinctions are not absolute - since moving for any reason give families a chance to optimize on location - the different types of moves provide expectations about differential average impacts of moving across types.

Our estimation of equation 5 can be thought of as estimating the weighted average of the various mobility effects across the different types of movers found in the sample. ${ }^{15}$ We do not know the motivation for any observed moves by students, but we can distinguish among types of moves and among families with differing income or racial/ethnic backgrounds. If these factors are correlated with move motivations, the weighted averages of changes in school quality will vary according to the differing proportions in the population. Thus, common assertions about mobility can be tested in terms of the weighted average outcomes for alternative groupings of student moves.

\footnotetext{
${ }^{14}$ Black (1999) and Weimer and Wolkoff (2001) do show, however, that within district school quality differences appear to be capitalized into house prices.

${ }^{15}$ The weighted average nature of the mobility coefficients helps to reconcile some of the previous variation in results across studies. Most of the prior studies rely on nonrepresentative samples and restrict attention to specific subsets of moves, such as moves within a single large district. 


\section{The UTD Texas Schools Microdata Panel}

The cornerstone of this research is the analysis of a unique microdata set of school operations constructed by the UTD Texas Schools Project, a project conceived of and directed by John Kain. The database tracks elementary students as they progress through school; it measures student performance each spring; and it contains detailed information about schools and teachers. This analysis follows three consecutive cohorts for three academic years each. The oldest cohort attended $5^{\text {th }}$ grade in 1994 and is followed through $7^{\text {th }}$ grade in 1996. The next cohort is also followed from $5^{\text {th }}$ to $7^{\text {th }}$ grade, while the youngest cohort is followed from $4^{\text {th }}$ to $6^{\text {th }}$ grade. For each cohort there are over 200,000 students in over 3,000 public schools. The large numbers of students who change schools and school districts are especially important for the methodology pursued here, as are the multiple cohorts which permit tracking of students who fall as far back as two grade levels behind their $4^{\text {th }}$ grade classmates or who move ahead as many as two grade levels.

Beginning in 1993, the Texas Assessment of Academic Skills (TAAS) was administered each spring to eligible students enrolled in grades three through eight. Unique IDs link the student records with the test data. ${ }^{16}$ The criteria referenced tests evaluate student mastery of grade-specific subject matter and provide our measure of student outcomes. We use mathematics test scores in this paper, although the results are qualitatively quite similar for reading achievement. Each math test contains approximately 50 questions. Because the number of questions and average percent right varies across time and grades, we transform all test results into standardized scores with a mean of zero and variance equal to one and included dummy variables for each grade/year combination. The regression results are robust to a number of transformations including the raw percentage correct.

\footnotetext{
${ }^{16}$ One important data consideration is the possibility that schools miscode student IDs, which would tend to depress the number of movers within the public schools and overstate the percentage who exit Texas public schools. While there is no sure check for coding errors, the evidence suggests that other types of coding problems are quite minimal. Less than one percent of observations in $4^{\text {th }}$ grade and less than one half of one percent of observations in $5^{\text {th }}$ thru $7^{\text {th }}$ grades did not have unique IDs in each cohort; note that a small number of duplicate records were deleted.
} 
The TAAS data are merged with a school attendance and teacher data. School attendance data provide information on school attended for each of six six-week periods during the school year, enabling us to identify the approximate timing of all school switches and those students who move multiple times during an academic year. Teacher data provide information on average class size, teacher turnover and teacher experienced which are used as controls in the analysis of student turnover.

While the data contain a limited number of student, family and program characteristics including race, ethnicity, gender and eligibility for a free or reduced price lunch, the panel feature can be exploited to account implicitly for time invariant individual effects on achievement. Importantly, students who switch schools can be followed as long as they remain in a Texas public school.

School transitions $\left(\mathrm{m}_{\mathrm{it}}\right)$ are constructed to exclude those that result from the structure of school districts. ${ }^{17}$ In other words, the transitions from elementary to middle and middle to junior high schools for students who remain in the same attendance zones are not considered moves, and the dummy variables for highest and lowest grade in a campus capture the effects of such transitions. A dummy variable indicating a new school is also included in all specifications.

\section{Student Mobility in Texas}

Texas schools mirror those in other parts of the nation: Switching schools is a regular part of academic life for many elementary school students. Table 3 presents the distribution of students by the number of moves during a three-year time frame for students who remain in the Texas public schools for the entire period. About one-third move at least once, though move frequencies vary by ethnicity and income. Only 25 percent of students never eligible for a subsidized lunch move even once, and only 5 percent move multiple times. In contrast, 40 percent of students eligible for a subsidized lunch in at least

\footnotetext{
${ }^{17}$ Because information on change of residence is not available, a school change was considered a structural change if the transition was to a school attended by more than 30 percent of previous classmates. Such structural transitions combine transitions between middle school and junior high with changes in attendance zones including the opening of new schools. 
one period move at least once, 10 percent move twice, and 7 percent move three or more times. The bottom three rows reveal similar differences by race and ethnicity.

Tables 4 through 7 focus on annual transitions. ${ }^{18}$ Table 4 examines differences by grade, Table 5 reports differences by timing and location of moves, and Tables 6 and 7 document mobility rates by origin and destination school community type.

The transitions reported in Table 4 reveal that exit rates from the Texas public school system tend to decline somewhat as students age, falling from 7.6 percent in $4^{\text {th }}$ grade to 6.1 percent in $7^{\text {th }}$ grade. ${ }^{19} \mathrm{~A}$ similar pattern holds for all demographic groups. In contrast, there is no strong grade pattern for school changes that holds for all demographic groups despite the existence of large differences across groups: the income and Black/White gap in annual transition rates are approximately 10 percentage points or 50 percent. The incidence of mobility and the differences by income level appear very consistent with those described previously for the nation as a whole.

Table 5 divides moves both by district changes and by timing and frequency. On average 8.4 percent of students transfer within the same district and another 13 percent switch districts annually. (A final 1.4 percent enters a school that did not previously exist, making it similar to a structural move between elementary and middle school). While Black and low income students are somewhat more likely to switch districts, the most pronounced differences by income and ethnicity occur in the probability of a within district switch. Blacks are almost three times as likely as Whites (14.7\% to 5.7\%) to change schools within district and Hispanics are almost twice as likely as Whites. Similarly, lower income students are roughly twice as likely to change schools within districts as higher income students. Though the national data do not distinguish between within district residential moves that did and did not result in school transfers, the patterns in Texas are qualitatively similar to those for the nation as a whole. In terms

\footnotetext{
${ }^{18}$ Note that the annual rates in these tables do not sum to the total number of moves reported in Table 3, because these tables include the mobility of students not in the Texas public schools at some point during the three year period.

${ }^{19}$ Exits combines two heterogeneous groups: those who leave the state entirely and those who leave the public schools for private schools within the state. We are unable to distinguish between these in our data. Moreover, while we do not consider the achievement effects, exiting from the sample clearly involves a school move.
} 
of timing, a substantial percentage (almost 10 percent) of students switch schools at least once during the school year, and the probabilities of multiple transfers within a year and moving during the school year present the largest differences by demographic group. Minority and lower income students are much more likely to move multiple times in a year and much more likely to move during the year.

The income and ethnic differences in within district changes in part reflect the fact that minorities and low income students are much more likely to attend public school in larger urban districts where within district moves are much more common. Almost fifty percent of Black and Hispanic students attend urban schools while only 20 percent of Whites attend public school in urban districts. There is also a 15 percentage point gap in urban attendance by income. Table 6 confirms that within district transfers are much more prevalent in urban districts, particularly large districts in major urban centers. Annually over 14 percent of students in urban schools transfer to another school within the same district; the corresponding figure for rural districts is only 2.5 percent (reflecting the fact that many have no within district alternative). Not surprisingly, rural and suburban students are somewhat more likely than urban students to change districts, though regardless of the origin community type there is a pronounced trend toward moving to suburban and rural districts. Among students who leave urban districts, almost 85 percent move to a suburban or rural district, while less than 30 percent of suburban students and 15 percent of rural students who switch districts move to an urban school.

Table 7 takes a more detailed look at mobility rates by destination community type, income and ethnicity for students attending large urban districts. Though there are substantial income and ethnic differences in the probability of moving within district, the probabilities of switching districts are much more similar. Hispanics are somewhat less likely to move to the suburbs, and Hispanics and Blacks are less likely to move to rural districts.

These five tables reveal a great deal about school transition rates along a number of dimensions. Even so, we lack detailed information on family circumstances, so we cannot adequately distinguish between cases of "distress" (such as job loss or divorce), Tiebout moves in search of better schools, and the majority of moves that result from employment changes or other factors. But the NLSY data make it 18 
clear that moving, whether within or across districts, is frequently accompanied by a variety of family changes.

\section{Individual Mobility Effects for Mathematics Achievement}

This section presents the results of the analysis of mobility effects on mathematics achievement. Two sets of estimates are reported for most specifications. The first subsumes all types of moves into a single variable, while the second divides moves on the basis of timing and location. Students who move a single time in a year are divided between district switchers who change regions, district switchers who remain in the same region, and those who move to a new school but remain in the same district. An additional variable indicates a move during the school year. ${ }^{20}$ Finally, those who switch multiple times in a year regardless of school location are grouped together. All specifications include indicators for the first grade in a campus, the final grade in a campus, a new school, subsidized lunch eligibility, and year-bygrade. ${ }^{21}$ Separate estimates are computed by ethnicity and income in order to investigate differences by demographic group. Following the discussion of the mobility estimates we consider the external effect of mobility on schoolmates.

\section{Basic Estimates}

Table 8 reports baseline estimates of the effects of different types of moves on achievement level in the highest grade and on annual achievement gains. The levels specification in the first pair of columns provides a direct comparison with other studies that utilize cross-sectional data. The second pair provides a benchmark for the basic value added specifications, but each undoubtedly confounds mobility effects and a variety of other selection factors. All standard errors (here and subsequently) are adjusted for the grouping of cohorts of students in schools, and the sample is restricted to students with valid test scores

\footnotetext{
${ }^{20}$ Preliminary work that allowed fully interacted the timing and location variables showed that the difference between pre year and during year move effects was very similar for both district switchers and those who moved within district. Subsequently we restricted the effects of within year moves to be the same for all students ${ }^{21}$ Year-by-grade indicators are included to allow for different tests in the various years. 19
} 
for four consecutive grades. Each pair of columns contains two separate estimating equations: the first aggregates all types of moves while the second separates moves by location and frequency.

Not surprisingly given the observed transition patterns, the estimates in the first column show that movers have significantly lower test scores and test score gains than nonmovers, particularly those who move multiple times. On average, for example, movers have math scores 0.17 standard deviations lower than nonmovers. Simple consideration of their lower achievement before the move using achievement gains, however, dramatically lowers the average estimate of moving costs to 0.027 standard deviations. Moreover, the disaggregated estimates suggest that different types of moves have different effects.

We now turn to the preferred specifications that include student fixed effects and that separate achievement growth in the year of a move from that in subsequent years. As described above, the coefficients for long run move effects $\left(\lambda^{*}\right)$ in Table 9 capture the change in school quality for movers (the "Tiebout effect"), while the coefficients on current mobility $(\lambda)$ conflate the change in school quality with the loss of school specific capital, other costs of disruption, school efforts to assimilate new entrants and the confounding influences of changes in family income or structure that may be associated with the move. Subtracting the coefficient on past mobility from the current mobility coefficient provides an estimate of the transitory components of the cost of moving, though we are unable to disentangle the specific underlying factors.

The top panel, which ignores differences in move timing or location, suggests that the average mover does not obtain any change in school quality (as indicated by the quite small and statistically insignificant coefficients for the total population and across all groups for long run impact, $\hat{\lambda}^{*}$ ). Achievement gains are significantly lower in the year of the move, though the extent to which that reflects a causal effect of mobility cannot be determined. However, assuming that mobility related factors such as divorce or income change on average exert a negative impact on achievement, the estimates suggest that the average transitional cost of moving is small, 0.02 standard deviations of achievement growth. 
Importantly, low income and minority students suffer somewhat larger average short run costs, which are not offset afterwards by any significant improvement in average school quality.

As hinted at in the previous table, however, the pattern of mobility effects clearly varies by type of move. The hypothesis that average school quality does not change for those who switch regions, move to a new school in the same district, or move multiple times cannot be rejected at any conventional level. But, those who move to a new district in the same region experience a significant average increase in school quality of 0.025 standard deviations. Importantly, because these estimates are computed over students whose families moved for a variety of reasons (including divorce), only some of which are associated with a search for better schooling, the magnitude 0.025 likely provides a lower bound estimate of the average improvement in school quality for 'Tiebout' movers who primarily switch districts to procure higher quality schooling.

Multiple movers experience somewhat larger academic setbacks on average. ${ }^{22}$ Surprisingly, the hypothesis that the timing of the move (i.e., moving during the school year) has no effect on the cost of moving cannot be rejected at any conventional level. Though we expected students who moved during the school year to experience larger transition costs, that was not the case.

\section{Differences by Race/Ethnicity and Income}

Another important issue is whether mobility effects vary systematically among demographic groups. The second and third columns of Table 9 report results for students ever classified as economically disadvantaged and those never classified respectively, and the final three columns present the findings for Blacks, Hispanics, and Whites respectively.

The estimates by income reveal some differences in the transitional costs associated with moving and in the average change in school quality. Both higher and lower income students who switch districts

\footnotetext{
${ }^{22}$ For multiple moves, based on preliminary disaggregations that were uninformative, no information is included on the location of any of the moves. The positive coefficient for long run effects for multiple movers is likely driven in part by the fact that multiple movers who remain in the same school in the subsequent year (and who identify the long run coefficient) suffer smaller losses on average than multiple movers who move again in the subsequent year. 21
} 
within region enjoy an average improvement in school quality of roughly 0.02 standard deviations per year, though the estimated gain is slightly lower for lower income students who also incur a larger cost in the year of the move. Lower income students who move multiple times and those who move within district also incur higher costs on average than higher income students for the same type of move. This does not imply that transition costs of moving are higher for lower income students, because the estimates cannot separate the transition costs from contemporaneous changes associated with the move. Lower income students may experience larger negative move-correlated shocks on average, perhaps because of the higher incidence of divorce reported in Table 2.

As would be expected given the strong link between income and ethnicity, the pattern of mobility estimates is fairly similar across demographic groups. One exception is that Black between district movers obtain no significant improvement in average school quality. Blacks who move within districts incur somewhat larger transition costs than Hispanics who in turn incur somewhat larger costs than Whites, while among those who make multiple moves in a year it is Hispanics who incur the higher average costs.

\section{Sensitivity Tests}

The interpretation of the long run difference in achievement growth as the change in school quality depends, as noted above, on three key but testable assumptions. Two specifications are used to examine whether unobserved changes over time in family circumstances or student recovery from the disruption of moving contaminate the estimates. The first includes a full set of leads and lags for each type of move, and the second divides between district moves by origin and destination community types.

Table 10 reports the estimates for between district moves within region which identify the average changes in achievement gains in the year prior to the move, the year of the move, the year following the move and the subsequent year. These results provide little or no evidence of either a temporary dip in achievement growth prior to the move or a temporary positive shock in the year following a move (driven by the recovery of achievement levels after the disruption). The coefficient on 22 
the one year lead is very small and insignificant, and the coefficients on the one year and two year lags are virtually identical. Clearly the gain following a move is neither concentrated in the single year following the year of the move nor spread out by lingering effects of disruptions. Thus, an improvement in school quality provides a much more plausible explanation for the steady long term average increase in achievement growth.

The division of between district moves on the basis of origin and destination community types provides additional support for the finding of a positive average change in school quality. A priori one would expect average school quality to rise more for students moving outside of urban districts than for those moving to an urban district. Table 11 finds this precise pattern. The average gain in school quality exceeds 0.03 standard deviations for students moving to non-urban districts, while it is negative for students moving to urban districts.

\section{Summary of Mobility Effects}

Two main findings emerge from the investigation of student mobility. First, district switchers tend to experience an improvement in school quality, but average school quality is largely unchanged following other types of moves. The exception is Blacks who obtain little or no gain on average from switching districts. Given that school quality considerations probably play a minor role in most decisions to relocate to a different region and knowledge of schools in the new region may be quite limited, it is not surprising that average school quality remains largely unchanged following such a move. It is also not surprising that within district movers experience no systematic gain in school quality. This result is consistent with Cullen, Jacobson and Levitt (2000), and likely reflects the fact that all schools within a district share a common central administration, financing system, and other factors. Moreover, in comparison to district switches, within district moves are less costly for the family and may be undertaken with lower expected benefits.

Second, despite the inability to disentangle the various components of transition costs, the total cost appears to be relatively small, particularly in comparison to the average achievement differences 23 
between movers and non-movers. While moving costs are slightly larger for lower income students and nonwhites and while they might impose severe burdens on some students, overall the costs of moving per se do not appear to impose a major impediment to academic success.

Finally, the evolution of the impacts of moving is an important consideration. The costs of moving are isolated in the year of the move, while the benefits for a student finding a better school accrue each year that the student remains in the new school.

\section{Externalities of Mobility}

Even if the transition cost of moving is small, school quality may be adversely affected by student turnover. New students may disrupt the classroom because of differences in skills and institutional knowledge. This may be a particular problem for high turnover schools in which there is substantial variation in academic preparation and large numbers of students who enter during the school year. The possibility that turnover effects non-movers as well as movers is raised by many including Alexander, Entwisle, and Dauber (1996) and Kerbow (1996), though neither attempts to estimate the impact of turnover on non-movers.

The methodological problem that must be overcome in identifying turnover effects is perhaps even more difficult than that for simple mobility effects, because sorting on the basis of school turnover rates may be even more systematic than differences between movers and nonmovers. In general all investigations of peer group effects share this concern.

Our approach concentrates on differences in achievement growth within schools. We examine the external effects of mobility using a model that removes student as well as school-by-grade fixed effects, using differences across cohorts in the change in turnover rates from one grade to the next to identify the effects of turnover. Consider a stylized school that offers both the $5^{\text {th }}$ and $6^{\text {th }}$ grade. Assume twenty percent of this year's $6^{\text {th }}$ grade class are new to the school, while only 15 percent of the students were new last year when the students were in $5^{\text {th }}$ grade. In comparison, last year's $6^{\text {th }}$ grade class had only 15 
percent new students in $6^{\text {th }}$ grade but 23 percent new students in $5^{\text {th }}$ grade. It is the within school difference in the change in percent new (20 percent minus 15 percent for the first cohort, 15 percent minus 22 percent for the second cohort) that we use to identify the external effects of turnover. Controlling for individual fixed effects in gains and mobility, we believe that these cross cohort differences are orthogonal to most other factors that systematically affect achievement gains and therefore identify the actual impact of school turnover.

Even a systematic moving pattern as students age that is related to achievement will not contaminate the estimates. For example, consider a school in a high poverty area in which mobility increases as students age while at the same time relative performance declines. Controlling for only student and school fixed effects will leave the estimates susceptible to contamination by those factors that evolve over time and affect both mobility and achievement, such as a greater difficulty attracting teachers as students age. However, the removal of school-by-grade fixed effects eliminates such systematic changes over time.

There are confounding school factors that may not be eliminated by the removal of school-bygrade fixed effects. One is average class size. If additional entrants tend to increase average class size, the negative effects of turnover may be confounded with the negative effects of larger average class sizes. A second is peer group quality. If new entrants tend to reduce peer average quality, the omission of information on peer quality may bias upward the estimated effect of turnover. Finally, teacher turnover and inexperience may be positively correlated with student turnover, and their exclusion may also bias upward the estimated effect of turnover. We consider each of these factors below.

Table 12 reports two sets of turnover effects. The first groups all new students into a single category, while the second separates students who enter prior to the start of the school year from those who enter during the year. The possibility that turnover affects movers and nonmovers differentially, perhaps because the effectiveness with which schools assimilate new entrants is a function of turnover, is also examined. We considered the possibility of nonlinear effects (not schown), but quadratic specifications provided no support for such nonlinearities. 
Again we begin with simple levels and gains specifications that treat all entrants as the same (across the top panel). Not surprisingly higher turnover is strongly associated with a lower level of achievement, but, as expected, the estimates decrease substantially as additional controls are included. The simple level-form model suggests that student turnover is three times as bad as that indicated in the models that more adequately control for individual and school differences.

Yet, the well-controlled estimates that include both student and school-by-grade fixed effects still reveal a strong negative relationship between achievement and turnover. Interestingly, from the final column, there is little evidence that turnover hurts movers differentially from nonmovers. This finding implies that the term for the effect of aggregate turnover on a school's ability to assimilate movers in equation 3 is unimportant.

The magnitude of the overall entry coefficient in the final column suggests that a one standard deviation increase in the proportion of students who are new to the school (an 11 percent change) would reduce achievement by almost 0.015 standard deviations. While a single year effect of this magnitude is not large, the sum total of ten or twelve years of high turnover will have a substantial cumulative effect on learning for those students who attend high turnover schools year after year.

The bottom panel of Table 12 shows that all turnover is not alike, as the negative effect of entrants during the school year is twice as large as the effect of entrants at the beginning of the school year. This pattern of estimates conforms with expectations that mid-year entrants are more disruptive to the education process.

Table 13 examines the sensitivity of these results to the inclusion of teacher characteristics and peer achievement. Specifically, high turnover at a school could simply be a proxy for other factors that affect achievement, such as more teacher turnover or poorer peers. To isolate the impact of student mobility per se, we include both a set of potentially important teacher factors (class size, proportion of new teachers, and the school's teacher turnover rate) and peer factors (average achievement of 
classmates). ${ }^{23}$ The estimates on the turnover variables remain virtually unchanged from those observed in Table 13 following the inclusion of the teacher and peer variables. This provides strong support for the interpretation that we have identified the impact of student turnover per se.

We also investigated the possibility that the sensitivity to turnover varies by demographic group. The estimates in Table 14 do not show that turnover affects Blacks more than Whites, though the estimates for Hispanics are somewhat larger than those for Whites. On the other hand, differences by income level - particularly for midyear turnover - are somewhat larger. Poor kids are more affected by the externalities of school mobility.

An important question is to what extent school turnover can account for the income differential in academic achievement. The direct effects on movers cannot explain much of the income gap, because the disruption costs of moving are small and isolated in the year of the move and both higher and lower income students obtain higher school quality on average following a between district move. ${ }^{24}$ However, the externality portion might account for a substantial portion of the achievement gap given the sizeable turnover coefficient for lower income students and the distinctly higher school turnover rates for lower income and nonwhite students (shown in Appendix Table A1). The proportion of students who enter during the year is more than 25 percent higher for the schools of lower income students.

Based on the differences in externalities of turnover for lower income students in the bottom panel of Table 13, the income differences in school turnover (both prior to and during the academic year) reduce academic achievement for lower income students relative to higher income students by roughly 0.0056 standard deviations per year. Seven years of such turnover differences would widen the income achievement gap by roughly 0.04 standard deviations, or about 6 percent of the achievement differential

\footnotetext{
${ }^{23}$ Hanushek, Kain and Rivkin (forthcoming) describe the estimation of peer group effects using the Texas data. We use peer average achievement of classmates lagged two years to break the potential link due to unobserved differences in teacher quality and to the simultaneous affect students have on one another. As a result, a number of observations including all those for fourth grade are dropped. Constructing average peer achievement based on test scores for the previous grade (the average achievement of peers at the start of the school year) generates virtually identical results.

${ }^{24}$ As indicated in Table 5, some small differences by income in the pattern of within district moves also exist, but these are too small to have a significant effect on the average achievement differences given the coefficients related to individual mobility. 
in $7^{\text {th }}$ grade. Given the large number of family, community and school factors that affect achievement, this effect is far from trivial.

A final consideration is the interactions of school turnover and the costs of moving. Appendix Table A2 shows that students who move within district arrive at schools with much higher turnover than those they left. The differential of 0.09 implies that school turnover alone reduces average achievement by 0.006 standard deviations, roughly 25 percent of the total achievement drop in the year of the move.

\section{Conclusions}

Consideration of school mobility has split between those emphasizing the disruption and harm to students and those emphasizing Tiebout choice of schools as a way that families can improve school quality. These opposing views have led to widely differing policy perspectives. At the same time, prior evidence on mobility effects has not reach a consensus on achievement implications, in large part we believe because the existing research has not identified or estimated the same parameters.

We develop a model of achievement growth that highlights the various avenues by which mobility can affect student achievement. Most existing empirical approaches are shown to estimate a net effect of moving that combines any changes in school quality with short run disruption costs. Moreover, the estimates almost certainly capture the effects of other changes such as divorce or job loss that are frequently associated with moving. With panel data of sufficient length, however, it is possible to develop a consistent estimate of school quality changes.

Our empirical analysis, conducted using the rich stacked panel data of the UTD Texas Schools Project, allows quite precise estimates of the effects of mobility. The results indicate that moves across districts yield a small but significant improvement in average school quality for all demographic groups except for Blacks. At the same time, moves within a district are associated with no significant changes in school quality but tend to involve noticeable short run costs - costs that are generally higher for poor and minority students. Since estimates of move effects are weighted averages across families moving for both 
school and nonschool reasons, the different estimated effects in part reflect the proportions of families motivated by different forces and likely underestimate the school quality gains for 'Tiebout' movers seeking a higher quality education.

School mobility also involves a clear externality. Schools with higher student turnover are shown to have significantly lower achievement than schools with lower turnover, all other things equal. These effects are felt by everyone in the school, not just those who themselves move. The impact on those who attend high turnover schools year in year out is far from trivial, because these effects cumulate over time. A student who attends school with a turnover rate of 50 percent rather than 20 percent for 12 years will lose roughly one half of a standard deviation in mathematics achievement. Moreover, students entering during a school year exert a greater negative impact than those entering at the beginning of the year. Lower income and nonwhite students on average attend schools with higher mobility rates both overall and during the year, subjecting them to a disadvantage that can accumulate to substantial losses in achievement. The negative effect of turnover also appears to be larger for lower income students for whom the cumulative cost of attending higher average turnover schools throughout their years in elementary and middle school is an impediment to their academic achievement.

\section{References}

Alexander, Karl L., Doris R. Entwisle, and Susan L. Dauber. "Children in motion: School transfers and elementary school performance." Journal of Educational Research 90, no. 1 (September/October 1996): 3-12.

Angrist, Joshua D., and Victor Lavy. "Using Maimondides' rule to estimate the effect of class size on scholastic achievement." Quarterly Journal of Economics 114, no. 2 (May 1999): 533-75.

Black, Sandra E. "Do better schools matter? Parental valuation of elementary education." Quarterly Journal of Economics 114, no. 2 (May 1999): 577-99.

Cullen, Julie Berry, Brian Jacob, and Steven Levitt. "The impact of school choice on student outcomes: An analysis of the Chicago public schools". Working Paper \#7888, National Bureau of Economic Research, Cambridge, MA, September 2000. 
Epple, Dennis, and Richard E. Romano. "Competition between private and public schools, vouchers, and peer-group effects." American Economic Review 88, no. 1 (March 1998): 33-62.

Fernandez, Raquel, and Richard Rogerson. "Education finance reform: A dynamic perspective." Journal of Policy Analysis and Management 16, no. 1 (Winter 1997): 67-84.

Hanushek, Eric A., John F. Kain, Jacob Markman, and Steven G. Rivkin. "Does peer ability affect student achievement?" Journal of Applied Econometrics. (Forthcoming)

Hoxby, Caroline Minter. "The effects of class size on student achievement: New evidence from population variation." Quarterly Journal of Economics 115, no. 3 (November 2000): 1239-85.

Ingersoll, Gary M., James P. Scamman, and Wayne D. Eckerling. "Geographic mobility and student achievement in an urban setting." Educational Evaluation and Policy Analysis 11, no. 2 (Summer 1989): 143-49.

Kain, John F., and Daniel M. O'Brien. "A longitudinal assessment of reading achievement: Evidence for the Harvard/UTD Texas Schools Project". UTD Texas Schools Project, University of Texas at Dallas, April 1998.

---. "Black suburbanization in Texas metropolitan areas and its impact on student achievement". Working paper, Green Center for the Study of Science and Society, University of Texas at Dallas, March 2000.

Kerbow, David. "Patterns of urban student mobility and local school reform." Journal of Education for Students Placed at Risk 1, no. 2 (1996): 147-69.

Nechyba, Thomas J. "Mobility, targeting, and private-school vouchers." American Economic Review 90, no. 1 (March 2000): 130-46.

Rivkin, Steven G., Eric A. Hanushek, and John F. Kain. "Teachers, schools, and academic achievement". National Bureau of Economic Research, Working Paper No. 6691 (revised) 2001.

Schacter, Jason. 2001a. Geographic mobility: March 1999 to March 2000. Current Population Reports, P20-538. Washington, DC: U.S. Census Bureau.

2001b. Why people move: Exploring the March 2000 Current Population Series. Current

Population Reports, P23-204. Washington, DC: U.S. Census Bureau.

Weimer, David L., and Michael J. Wolkoff. "School performance and housing values: Using noncontiguous district and incorporation boundaries to identify school effects." National Tax Journal 54, no. 2 (June 2001), pp. 251-253. 
Table 1. Aggregate U.S. Moving Outcomes from Students age 9-14, 1994-96 by poverty status

\begin{tabular}{l|c|c|c|}
\cline { 3 - 4 } & \multirow{2}{*}{ Nonmovers } & \multicolumn{2}{|c|}{ Movers } \\
\cline { 3 - 4 } & & within district & across districts \\
\hline all & $55.4 \%$ & $31.3 \%$ & $13.3 \%$ \\
disadvantaged & $50.5 \%$ & $34.7 \%$ & $14.9 \%$ \\
not disadvantaged & $59.3 \%$ & $28.7 \%$ & $12.1 \%$
\end{tabular}

Source: NLSY79 
Table 2. Concomitant Family Changes for Students age 9-14, 1994-96 by poverty status (percents)

\begin{tabular}{|c|c|c|c|}
\hline & \multirow{2}{*}{ Nonmovers } & \multicolumn{2}{|c|}{ Movers } \\
\hline & & \multicolumn{2}{|c|}{\begin{tabular}{|l|l|} 
within district across districts \\
\end{tabular}} \\
\hline \multicolumn{4}{|l|}{ Disadvantaged } \\
\hline Family status changed & 19.6 & 20.2 & 27.5 \\
\hline Got divorced/separated & 10.6 & 15.5 & 22.2 \\
\hline Employment status of mother changed & 25.7 & 27.4 & 29.8 \\
\hline Became unemployed & 6.6 & 8.2 & 18.1 \\
\hline Employment status of spouse changed & 17.2 & 27.5 & 32.1 \\
\hline Became unemployed & 8.0 & 12.5 & 25.0 \\
\hline \multicolumn{4}{|l|}{ Not disadvantaged } \\
\hline Family status changed & 12.5 & 19.1 & 28.0 \\
\hline Got divorced/separated & 8.7 & 10.7 & 14.0 \\
\hline Employment status of mother changed & 16.5 & 15.6 & 20.4 \\
\hline Became unemployed & 5.5 & 5.5 & 6.8 \\
\hline Employment status of spouse changed & 9.9 & 12.1 & 10.0 \\
\hline Became unemployed & 4.0 & 7.0 & 6.7 \\
\hline
\end{tabular}

Source: NLSY79 
Table 3. Distribution of Texas Public School Students by the Number of School Changes between 4th and 7th Grade, by Income and Ethnicity

\begin{tabular}{|c|c|c|c|c|c|c|c|}
\hline & \multicolumn{6}{|c|}{ Number of School Changes } & \multirow[b]{2}{*}{$\begin{array}{c}\text { Number of } \\
\text { students }\end{array}$} \\
\hline & 0 & 1 & 2 & 3 & 4 & $5+$ & \\
\hline All Students & $66.1 \%$ & $21.8 \%$ & $7.6 \%$ & $2.7 \%$ & $1.0 \%$ & $0.8 \%$ & 701,311 \\
\hline ever low income & $59.6 \%$ & $23.5 \%$ & $10.0 \%$ & $4.0 \%$ & $1.6 \%$ & $1.2 \%$ & 406,843 \\
\hline never low income & $75.0 \%$ & $19.5 \%$ & $4.2 \%$ & $0.9 \%$ & $0.2 \%$ & $0.1 \%$ & 294,458 \\
\hline Black & $52.4 \%$ & $27.5 \%$ & $12.2 \%$ & $4.8 \%$ & $1.9 \%$ & $1.3 \%$ & 96,699 \\
\hline Hispanic & $64.7 \%$ & $22.3 \%$ & $8.0 \%$ & $3.0 \%$ & $1.1 \%$ & $0.8 \%$ & 247,771 \\
\hline White & $70.9 \%$ & $19.7 \%$ & $6.0 \%$ & $2.0 \%$ & $0.8 \%$ & $0.6 \%$ & 341,041 \\
\hline
\end{tabular}

Note: Sample restricted to students in sample three complete years and in the final period in the prior year. School changes exclude structural changes of going from elementary to middle school or going to a newly constructed school. 
Table 4. Average Annual Probabilities of Switching Schools and Exiting the Texas Public School System Between Grades 4 and 7, by Grade, Income and Ethnicity

\begin{tabular}{|c|c|c|c|c|c|c|}
\hline & \multicolumn{2}{|c|}{ Ever Low Income } & \multicolumn{3}{|c|}{ Ethnicity } & \multirow[b]{2}{*}{ All } \\
\hline & Yes & No & Black & Hispanic & White & \\
\hline \multicolumn{7}{|c|}{ School Switches } \\
\hline All Grades & $26.4 \%$ & $17.6 \%$ & $30.2 \%$ & $24.0 \%$ & $19.6 \%$ & $22.8 \%$ \\
\hline Grade 4 & $28.1 \%$ & $18.1 \%$ & $31.2 \%$ & $24.7 \%$ & $21.1 \%$ & $23.9 \%$ \\
\hline Grade 5 & $25.6 \%$ & $16.3 \%$ & $27.8 \%$ & $22.6 \%$ & $19.3 \%$ & $21.7 \%$ \\
\hline Grade 6 & $27.2 \%$ & $18.6 \%$ & $32.6 \%$ & $24.9 \%$ & $19.9 \%$ & $23.6 \%$ \\
\hline Grade 7 & $25.6 \%$ & $17.8 \%$ & $30.0 \%$ & $24.2 \%$ & $18.7 \%$ & $22.4 \%$ \\
\hline \multicolumn{7}{|c|}{ Exit Texas Public Schools } \\
\hline All Grades & $7.2 \%$ & $6.2 \%$ & $7.2 \%$ & $6.9 \%$ & $6.6 \%$ & $6.8 \%$ \\
\hline Grade 4 & $7.7 \%$ & $7.4 \%$ & $8.8 \%$ & $7.5 \%$ & $7.3 \%$ & $7.6 \%$ \\
\hline Grade 5 & $7.1 \%$ & $6.1 \%$ & $7.1 \%$ & $6.8 \%$ & $6.5 \%$ & $6.7 \%$ \\
\hline Grade 6 & $6.9 \%$ & $6.5 \%$ & $6.8 \%$ & $6.6 \%$ & $6.8 \%$ & $6.7 \%$ \\
\hline Grade 7 & $6.7 \%$ & $5.3 \%$ & $6.6 \%$ & $6.2 \%$ & $5.9 \%$ & $6.1 \%$ \\
\hline
\end{tabular}


Table 5. Average Annual Probabilities of Switching Schools Between Grades 4 and 7, by Type of Move, Income and Ethnicity

\begin{tabular}{|c|c|c|c|c|c|c|}
\hline & \multicolumn{2}{|c|}{ Ever Low Income } & \multicolumn{3}{|c|}{ Ethnicity } & \multirow[b]{2}{*}{ All } \\
\hline & Yes & No & Black & Hispanic & White & \\
\hline All School Switches & $26.4 \%$ & $17.6 \%$ & $30.2 \%$ & $24.0 \%$ & $19.6 \%$ & $22.8 \%$ \\
\hline \multicolumn{7}{|l|}{ By Timing } \\
\hline Prior to school year & $14.9 \%$ & $12.4 \%$ & $18.4 \%$ & $14.1 \%$ & $12.2 \%$ & $13.9 \%$ \\
\hline During school year & $7.1 \%$ & $3.9 \%$ & $7.0 \%$ & $6.4 \%$ & $5.0 \%$ & $5.8 \%$ \\
\hline Multiple moves & $4.4 \%$ & $1.2 \%$ & $4.8 \%$ & $3.4 \%$ & $2.4 \%$ & $3.1 \%$ \\
\hline \multicolumn{7}{|l|}{ By School Location } \\
\hline Same district & $10.7 \%$ & $5.3 \%$ & $14.7 \%$ & $9.7 \%$ & $5.7 \%$ & $8.4 \%$ \\
\hline New district, same region & $13.7 \%$ & $11.7 \%$ & $12.2 \%$ & $11.4 \%$ & $10.6 \%$ & $11.2 \%$ \\
\hline New region & $13.7 \%$ & $11.7 \%$ & $1.4 \%$ & $1.3 \%$ & $2.3 \%$ & $1.8 \%$ \\
\hline $\begin{array}{l}\text { Move to new schools both in and } \\
\text { out of district }\end{array}$ & $2.0 \%$ & $0.6 \%$ & $2.1 \%$ & $1.6 \%$ & $1.0 \%$ & $1.4 \%$ \\
\hline
\end{tabular}


Table 6. Destination School Community Type by Origin School Community Type

(computations based on school enrollment at time of test administration)

\begin{tabular}{cccccccc} 
Origin Community & no move & new school & \multicolumn{3}{c}{ Destination in new district } & Number of \\
\cline { 5 - 6 } & & same district & large urban & small urban & suburban & rural & Observations \\
\hline Large Urban & $77.6 \%$ & $15.0 \%$ & $0.9 \%$ & $0.3 \%$ & $4.8 \%$ & $1.3 \%$ & 477,873 \\
Small Urban & $80.4 \%$ & $13.8 \%$ & $0.4 \%$ & $0.6 \%$ & $3.0 \%$ & $1.8 \%$ & 298,095 \\
Suburban & $84.6 \%$ & $7.5 \%$ & $1.5 \%$ & $0.8 \%$ & $3.8 \%$ & $1.8 \%$ & 898,898 \\
Rural & $89.7 \%$ & $2.5 \%$ & $0.5 \%$ & $0.6 \%$ & $1.7 \%$ & $5.0 \%$ & 697,812
\end{tabular}

Note: Moves are categorized based on the primary district in the central city of the largest nine metropolitan areas (large urban), the primary district in the central city of the remaining metropolitan areas (small urban), districts in the suburbs of metropolitan areas (suburban), and districts in the remaining areas of the state (rural). See also footnote 12. 
Table 7. Destination School Community Type for Students in Large Urban Districts, by Income and Ethnicity (computations based on school enrollment at time of test administration)

\begin{tabular}{|c|c|c|c|c|c|c|c|}
\hline \multirow[b]{2}{*}{ Origin Community } & \multirow[b]{2}{*}{ no move } & \multirow{2}{*}{$\begin{array}{c}\text { new school } \\
\text { same district }\end{array}$} & \multicolumn{4}{|c|}{ Destination in new district } & \multirow{2}{*}{$\begin{array}{c}\text { Number of } \\
\text { Observations }\end{array}$} \\
\hline & & & large urban & small urban & suburban & rural & \\
\hline \multicolumn{8}{|l|}{ Ever low income } \\
\hline Yes & $76.0 \%$ & $16.4 \%$ & $1.0 \%$ & $0.3 \%$ & $4.9 \%$ & $1.3 \%$ & 367,726 \\
\hline No & $82.9 \%$ & $10.5 \%$ & $0.4 \%$ & $0.4 \%$ & $4.4 \%$ & $1.4 \%$ & 110,110 \\
\hline \multicolumn{8}{|l|}{ Ethnicity } \\
\hline Black & $70.4 \%$ & $22.2 \%$ & $0.4 \%$ & $0.3 \%$ & $5.6 \%$ & $1.1 \%$ & 117,095 \\
\hline Hispanic & $80.2 \%$ & $13.5 \%$ & $1.2 \%$ & $0.3 \%$ & $3.9 \%$ & $0.9 \%$ & 258,444 \\
\hline White & $79.3 \%$ & $10.5 \%$ & $0.6 \%$ & $0.5 \%$ & $6.0 \%$ & $3.0 \%$ & 93,336 \\
\hline
\end{tabular}

Note: Moves are categorized based on the primary district in the central city of the largest nine metropolitan areas (large urban), the primary district in the central city of the remaining metropolitan areas (small urban), districts in the suburbs of metropolitan areas (suburban), and districts in the remaining areas of the state (rural). See also footnote 12 . 
Table 8. Estimated Effects of Moving $(\lambda)$ on Mathematics Achievement Test Score and Test Score Gain during Grades 4, 5, 6, and 7, By Type and

Timing of Move (absolute value of Huber-White adjusted $t$ statistics in parentheses)

\begin{tabular}{|c|c|c|c|c|}
\hline \multirow{2}{*}{$\begin{array}{l}\text { All Moves Combined } \\
\text { move to new school }\end{array}$} & \multicolumn{2}{|c|}{$\begin{array}{l}\text { Score in Highest } \\
\text { Grade }\end{array}$} & \multicolumn{2}{|c|}{$\begin{array}{l}\text { Annual } \\
\text { Gain }\end{array}$} \\
\hline & $\begin{array}{l}-0.170 \\
(24.53)\end{array}$ & & $\begin{array}{l}-0.027 \\
(10.35)\end{array}$ & \\
\hline $\begin{array}{l}\text { Location } \\
\text { move to new district } \\
\text { in same region }\end{array}$ & & $\begin{array}{l}-0.095 \\
(10.02)\end{array}$ & & $\begin{array}{l}-0.005 \\
(1.25)\end{array}$ \\
\hline move to new region & & $\begin{array}{l}0.031 \\
(2.83)\end{array}$ & & $\begin{array}{l}0.013 \\
(2.64)\end{array}$ \\
\hline move within district & & $\begin{array}{l}-0.088 \\
(7.62)\end{array}$ & & $\begin{array}{l}-0.035 \\
(8.63)\end{array}$ \\
\hline move during year & & $\begin{array}{l}-0.247 \\
(21.44)\end{array}$ & & $\begin{array}{l}-0.012 \\
(2.28)\end{array}$ \\
\hline More Than One Move & & $\begin{array}{l}-0.422 \\
(34.35)\end{array}$ & & $\begin{array}{c}-0.053 \\
(10.31)\end{array}$ \\
\hline observations & 493,777 & 493,777 & $1,482,141$ & $1,482,141$ \\
\hline
\end{tabular}

Note: All specifications include indicator variables for highest and lowest grades in a campus, new schools, student eligibility for a subsidized lunch, and grade-by-year . 
Table 9. Estimated Effects of Moving on Mathematics Achievement Test Score Gain during Grades 4, 5, 6, and 7, by Type and Timing of Move, Income and Ethnicity (absolute value of Huber-White adjusted $t$ statistics in parentheses)

\begin{tabular}{|c|c|c|c|c|c|c|c|}
\hline & & & Ever 1 & ncome & & ace/ethnic & \\
\hline & & All & Yes & No & Black & Hispanic & White \\
\hline A. All moves & ned & & & & & & \\
\hline ? & & -0.014 & -0.026 & -0.004 & -0.036 & -0.025 & 0.001 \\
\hline & & (3.09) & $(4.24)$ & $(0.72)$ & $(3.19)$ & $(3.22)$ & $(0.19)$ \\
\hline$\lambda$ & & 0.006 & 0.002 & 0.002 & 0.005 & 0.005 & 0.001 \\
\hline & & $(1.05)$ & $(0.32)$ & $(0.32)$ & $(0.38)$ & $(0.50)$ & $(0.23)$ \\
\hline B. Moves by ? & and & ct Patte & & & & & \\
\hline & $\lambda$ & 0.009 & 0.000 & 0.019 & -0.016 & -0.008 & 0.027 \\
\hline $\begin{array}{l}\text { Same } \\
\text { Region, }\end{array}$ & & (1.42) & $(0.06)$ & $(2.14)$ & $(0.92)$ & $(0.71)$ & $(3.43)$ \\
\hline New & & & & & & & \\
\hline & $\lambda^{*}$ & 0.025 & 0.022 & 0.024 & 0.003 & 0.032 & 0.030 \\
\hline & & $(3.10)$ & (1.93) & $(2.28)$ & $(0.13)$ & (1.98) & $(3.16)$ \\
\hline & $\lambda$ & -0.024 & -0.031 & -0.019 & -0.042 & -0.022 & -0.011 \\
\hline $\begin{array}{l}\text { Same } \\
\text { Region, }\end{array}$ & & $(3.87)$ & $(3.81)$ & $(2.59)$ & $(3.10)$ & $(2.28)$ & $(1.52)$ \\
\hline Same & & & & & & & \\
\hline District & $\lambda^{*}$ & -0.003 & -0.006 & -0.006 & -0.001 & -0.009 & -0.009 \\
\hline & & $(0.33)$ & $(0.54)$ & $(0.60)$ & $(0.05)$ & $(0.71)$ & $(0.92)$ \\
\hline & $\lambda$ & 0.010 & 0.000 & 0.014 & -0.026 & -0.007 & 0.023 \\
\hline $\begin{array}{l}\text { New } \\
\text { Region, }\end{array}$ & & $(1.21)$ & $(0.02)$ & $(1.38)$ & $(0.92)$ & $(0.40)$ & $(2.42)$ \\
\hline New & & & & & & & \\
\hline District & $\lambda^{*}$ & -0.010 & -0.021 & -0.005 & -0.001 & 0.006 & -0.013 \\
\hline & & $(0.90)$ & $(1.30)$ & $(0.38)$ & $(0.02)$ & $(0.27)$ & $(1.03)$ \\
\hline & $\lambda$ & -0.005 & -0.013 & 0.009 & 0.002 & -0.016 & -0.015 \\
\hline $\begin{array}{l}\text { Move } \\
\text { During }\end{array}$ & & $(0.75)$ & $(1.52)$ & $(0.85)$ & $(0.15)$ & $(1.35)$ & $(1.60)$ \\
\hline Academic & & & & & & & \\
\hline Year & $\lambda^{*}$ & 0.004 & 0.005 & 0.003 & 0.027 & 0.001 & -0.006 \\
\hline & & $(0.45)$ & $(0.43)$ & $(0.19)$ & (1.12) & $(0.06)$ & $(0.44)$ \\
\hline & $\lambda$ & -0.028 & -0.041 & -0.020 & -0.036 & -0.044 & -0.024 \\
\hline $\begin{array}{l}\text { Multiple } \\
\text { Moves in }\end{array}$ & & $(3.24)$ & $(4.08)$ & $(1.15)$ & (1.79) & $(3.05)$ & $(1.92)$ \\
\hline Academic & $\lambda *$ & & & & & & \\
\hline year & $\lambda^{*}$ & $\begin{array}{l}0.024 \\
(1.92)\end{array}$ & $\begin{array}{l}0.017 \\
(1.17)\end{array}$ & $\begin{array}{l}0.007 \\
(0.32)\end{array}$ & $\begin{array}{l}0.015 \\
(0.47)\end{array}$ & $\begin{array}{l}0.041 \\
(1.88)\end{array}$ & $\begin{array}{l}0.001 \\
(0.06)\end{array}$ \\
\hline observations & & 141 & 710,038 & 765,475 & 193,000 & 438,386 & 818,453 \\
\hline
\end{tabular}

Note: The top and bottom panels represent separate regressions based on equation 5. All specifications estimated with student fixed effects and include indicator variables for highest and lowest grades in a campus, new schools, student eligibility for a subsidized lunch, and grade-by-year . 
Table 10. Student Fixed Effect Estimates of the Change in Achievement Gains for Between District Moves within Region Prior to and Following a Move (absolute value of Huber-White adjusted $t$ statistics in parentheses)

\begin{tabular}{cc} 
& $\begin{array}{c}\text { Same region, } \\
\text { New district }\end{array}$ \\
\hline$\lambda_{-1}$ & -0.005 \\
& $(0.52)$ \\
$\lambda$ & 0.003 \\
& $(0.35)$ \\
$\lambda_{1}{ }^{*}$ & 0.019 \\
& $(1.86)$ \\
$\lambda_{2}{ }^{*}$ & 0.017 \\
& $(1.33)$
\end{tabular}

Note: The $\lambda$ 's in the table are estimated coefficients for a series of time specific indicator variables. $\mathrm{m}_{-1}=1$ in year prior to move; $=0$ otherwise. $\mathrm{m}=1$ in year of move; $=0$ otherwise. $\mathrm{m}_{1^{*}}=1$ in year after move; $=0$ otherwise. $\mathrm{m}_{2^{*}}=1$ in second year after move; $=0$ otherwise. 
Table 11. Student Fixed Effect Estimates of the Change in Achievement Gains for Between District Moves by Origin and Destination Community Type (absolute value of Huber-White adjusted $t$ statistics in parentheses)

\begin{tabular}{ccccc} 
& \multicolumn{2}{c}{ From central city to: } & \multicolumn{2}{c}{ From suburban/rural to: } \\
& Central city & Suburban/rural & Central city & Suburban/rural \\
\hline$\lambda$ & -0.061 & -0.001 & 0.007 & 0.021 \\
& $(2.03)$ & $(0.51)$ & $(0.44)$ & $(2.64)$ \\
$\lambda^{*}$ & -0.041 & 0.030 & -0.023 & 0.033 \\
& $(0.94)$ & $(1.86)$ & $(1.00)$ & $(3.20)$
\end{tabular}

Note: Moves are categorized based on the largest district in the central city of metropolitan areas and the remaining areas. See footnote 12 . 
Table 12. Estimated Effects of Proportions of Students Who Are New to the Class on Achievement Gain, By timing of entry (absolute value of Huber-White adjusted t statistics in parentheses)

\begin{tabular}{|c|c|c|}
\hline \multirow{2}{*}{$\begin{array}{c}\text { Score in highest } \\
\text { grade }\end{array}$} & \multicolumn{2}{|c|}{ Annual achievement gains } \\
\cline { 2 - 3 } & $\begin{array}{c}\text { without fixed } \\
\text { effects }\end{array}$ & $\begin{array}{c}\text { with student and school-by- } \\
\text { grade fixed effects }\end{array}$ \\
\hline
\end{tabular}

\begin{tabular}{|c|c|c|c|c|c|c|}
\hline \multicolumn{7}{|l|}{ A. Combined impact } \\
\hline proportion new entrants & $\begin{array}{l}-0.41 \\
(9.08)\end{array}$ & & $\begin{array}{c}-0.20 \\
(10.76)\end{array}$ & & $\begin{array}{l}-0.12 \\
(4.00)\end{array}$ & \\
\hline \multicolumn{7}{|c|}{ proportion new entrants*moved } \\
\hline \multicolumn{7}{|l|}{ B. Impact by timing of entry } \\
\hline proportion of students & & -0.14 & & -0.18 & & -0.06 \\
\hline entering at start of year & & $(3.00)$ & & $(9.65)$ & & (1.99) \\
\hline proportion of students & & -0.98 & & -0.06 & & -0.12 \\
\hline entering during year & & $(14.29)$ & & $(1.04)$ & & $(2.31)$ \\
\hline
\end{tabular}

Note: All specifications include indicator variables for student eligibility for a subsidized lunch and grade-by-year. Except for the last three columns, the specifications also include indicator variables for highest and lowest grades in a campus and new schools, 
Table 13. Estimated Effects of Proportions of Students Who Are New to the Class on Achievement Gain Controlling for Teacher and Peer Characteristics (absolute value of Huber-White adjusted $t$ statistics in parentheses)

\begin{tabular}{|c|c|c|c|}
\hline & $\begin{array}{l}\text { With no teacher or peer } \\
\text { characteristics }\end{array}$ & $\begin{array}{l}\text { With teacher } \\
\text { characteristics }\end{array}$ & $\begin{array}{l}\text { With teacher and peer } \\
\text { characteristics }\end{array}$ \\
\hline Proportion new entrants & $\begin{array}{l}-0.14 \\
(4.28)\end{array}$ & $\begin{array}{l}-0.14 \\
(4.12)\end{array}$ & $\begin{array}{l}-0.14 \\
(4.04)\end{array}$ \\
\hline $\begin{array}{l}\text { proportion of students } \\
\text { entering at start of year }\end{array}$ & $\begin{array}{l}-0.08 \\
(2.06)\end{array}$ & $\begin{array}{l}-0.06 \\
(1.72)\end{array}$ & $\begin{array}{l}-0.06 \\
(1.65)\end{array}$ \\
\hline $\begin{array}{l}\text { proportion of students } \\
\text { entering during year }\end{array}$ & $\begin{array}{l}-0.11 \\
(1.75)\end{array}$ & $\begin{array}{l}-0.12 \\
(1.95)\end{array}$ & $\begin{array}{l}-0.12 \\
(1.95)\end{array}$ \\
\hline
\end{tabular}

Note: All specifications include indicator variables for student eligibility for a subsidized lunch and grade-by-year along with student and school-by-grade fixed effects. Peer achievement calculations use achievement two years in the past; consequently 4 th grade is dropped. Teacher characteristics include class size, proportion of teachers with zero years of experience, and teacher turnover rate in the school. 
Table 14. Estimated Effects of Proportions of Students Who Are New to the Class on Achievement Gain, By timing of entry, Income, and Ethnicity (absolute value of Huber-White adjusted t statistics in parentheses)

\begin{tabular}{|c|c|c|c|c|c|}
\hline & \multicolumn{2}{|c|}{ Ever low income } & \multicolumn{3}{|c|}{ Race/ethnicity } \\
\hline & Yes & No & Black & Hispanic & White \\
\hline proportion new entrants & $\begin{array}{l}-0.16 \\
(4.55)\end{array}$ & $\begin{array}{l}-0.09 \\
(2.71)\end{array}$ & $\begin{array}{l}-0.07 \\
(1.17)\end{array}$ & $\begin{array}{l}-0.15 \\
(3.54)\end{array}$ & $\begin{array}{l}-0.12 \\
(3.60)\end{array}$ \\
\hline $\begin{array}{l}\text { proportion of students } \\
\text { entering at start of year }\end{array}$ & $\begin{array}{l}-0.07 \\
(1.73)\end{array}$ & $\begin{array}{l}-0.06 \\
(1.70)\end{array}$ & $\begin{array}{c}0.01 \\
(0.21)\end{array}$ & $\begin{array}{l}-0.07 \\
(1.42)\end{array}$ & $\begin{array}{l}-0.07 \\
(2.10)\end{array}$ \\
\hline $\begin{array}{l}\text { proportion of students } \\
\text { entering during year }\end{array}$ & $\begin{array}{l}-0.21 \\
(4.24)\end{array}$ & $\begin{array}{c}0.01 \\
(0.20)\end{array}$ & $\begin{array}{l}-0.10 \\
(1.09)\end{array}$ & $\begin{array}{c}-0.24 \\
(3.54)\end{array}$ & $\begin{array}{l}-0.06 \\
(0.86)\end{array}$ \\
\hline
\end{tabular}

Note: All estimated models include individual student and school-by-grade fixed effects along with indicator variables, student eligibility for a subsidized lunch, and grade-by-year. 


\section{Appendix Table A1. Mean proportion of students who are new, by ethnicity}

and income (standard deviations in parentheses)

\begin{tabular}{|c|c|c|c|c|c|c|}
\hline & \multicolumn{2}{|c|}{ Ever low income } & \multicolumn{3}{|c|}{ Ethnicity } & \multirow[b]{2}{*}{ All } \\
\hline & yes & no & Black & Hispanic & White & \\
\hline proportion new entrants & $\begin{array}{c}0.23 \\
(0.12)\end{array}$ & $\begin{array}{c}0.20 \\
(0.10)\end{array}$ & $\begin{array}{c}0.26 \\
(0.13)\end{array}$ & $\begin{array}{c}0.22 \\
(0.11)\end{array}$ & $\begin{array}{c}0.20 \\
(0.10)\end{array}$ & $\begin{array}{c}0.22 \\
(0.11)\end{array}$ \\
\hline $\begin{array}{l}\text { Proportion of students } \\
\text { entering at start of year }\end{array}$ & $\begin{array}{c}0.17 \\
(0.11)\end{array}$ & $\begin{array}{c}0.15 \\
(0.10)\end{array}$ & $\begin{array}{c}0.20 \\
(0.13)\end{array}$ & $\begin{array}{c}0.16 \\
(0.10)\end{array}$ & $\begin{array}{c}0.15 \\
(0.09)\end{array}$ & $\begin{array}{c}0.16 \\
(0.10)\end{array}$ \\
\hline $\begin{array}{l}\text { Proportion of students } \\
\text { entering during year }\end{array}$ & $\begin{array}{c}0.09 \\
(0.06)\end{array}$ & $\begin{array}{c}0.07 \\
(0.04)\end{array}$ & $\begin{array}{c}0.10 \\
(0.07)\end{array}$ & $\begin{array}{c}0.09 \\
(0.05)\end{array}$ & $\begin{array}{c}0.07 \\
(0.04)\end{array}$ & $\begin{array}{c}0.08 \\
(0.05)\end{array}$ \\
\hline
\end{tabular}

Appendix Table A2. Average Proportion of Students Who Are New to the Class and Change in Proportion New, by Type and Timing of Move

\begin{tabular}{lcc} 
& $\begin{array}{c}\text { proportion } \\
\text { new entrants }\end{array}$ & $\begin{array}{c}\text { change in } \\
\text { proportion new entrants }\end{array}$ \\
\hline All students & 0.21 & -0.02 \\
Nonmovers & 0.29 & 0.05 \\
Movers & & \\
Mover Outcome by Location & 0.25 & 0.00 \\
New district, same region & 0.23 & 0.00 \\
New region & 0.35 & 0.09 \\
Move within district & 0.27 & 0.04 \\
Move during year & 0.30 & 0.05 \\
Move more than once &
\end{tabular}

